\title{
Greve dos Caminhoneiros e a diminuição dos poluentes monóxido de carbono e óxidos de nitrogênio e o aumento do ozônio na Região Metropolitana de São Paulo
}

Debora Souza Alvim¹, José Roberto Rozante ${ }^{1}$, Júlio Barboza Chiquetto², Vinícius Rozante ${ }^{3}$, João Paulo Gobbo Assis ${ }^{4}$, Marlon Faria ${ }^{5}$

\footnotetext{
${ }^{1}$ Instituto Nacional de Pesquisas Espaciais ${ }^{2}$ Instituto de Estudos Avançados da Universidade de São Paulo ${ }^{3}$ Universidade Estadual de Campinas ${ }^{4}$ Universidade Federal de Rondônia ${ }^{5}$ Universidade de São Paulo deborasalvim@gmail.com
}

\section{Resumo}

A poluição do ar tornou-se um dos fatores que mais afetam a qualidade de vida da população, ocasionando prejuizos à saude humana e ao meio ambiente. Emissões de gases por veiculos automotores comprometem significativamente a qualidade do ar na Região Metropolitana de São Paulo (RMSP) por liberarem grande quantidade de monoxido de carbono ( $\mathrm{CO}$ ), óxidos de nitrogênio (NOx), compostos orgânicos voláteis e estes poluentes formarão ozônio (O3). 